\title{
\$40m plant genome sequencing effort targets the best science
}

[WASHINGTON] The US National Science Foundation (NSF), under instructions from Congress to launch a plant genome research programme following intensive lobbying by the US Corn Growers' Association, appears to have succeeded in framing the initiative on its own, scientifically rigorous, terms.

The NSF says it will award more than $\$ 30$ million next year to teams of researchers who present the best ideas for investigating the genomes of 'economically significant' plants. Money will not be allocated in advance for the investigation of any particular crop, but will instead be sent to where NSF reviewers see the best science.

Mary Clutter, head of the NSF's directorate of biological sciences, says that the announcement reflects NSF's "ordinary way of doing business". Asked what direction the programme will take, she says: "We're going to ask the scientific community to make proposals, and find out."

The programme is being rushed into place after Senate appropriators, led by Senator Christopher Bond (Republican, Missouri), earmarked $\$ 40$ million for it in the current financial year, which ends next September (see Nature 388, 312; 1997). Clutter met Senate staff last week to update them on the initiative's progress, and convinced them that the NSF will make it work. "I think NSF is embracing it as a good initiative," a staff member said afterwards.

But concerns remain. Some researchers doubt whether the programme can meet what they see as the corn growers' inflated expectations of immediate outcomes, and retain funding long enough to bear fruit.

Others worry about the principle of the NSF - an agency whose primary mission is to support science being conducted for its own sake - running errands for an influential senator from an agricultural state who happens to chair the appropriations subcommittee that funds it.

This week's announcement asks researchers for proposals that will cost up to $\$ 3$ million a year for between one and five years. The document envisages 'virtual centres' involving collaborators at many institutions, addressing questions on gene sequence and function from many angles.

Participants will be required to coordinate their work with existing international projects, such as the Japan-led effort to sequence the rice genome. No money will be available for new infrastructure or buildings.

As well as plant geneticists, Clutter hopes to see computer scientists, mathematicians and engineers involved in proposals that take new approaches to the study of plant genomes. Much of the work will use

\section{UK institutes club together to win sponsors}

[LONDON] Keen to boost their joint scientific capabilities and appeal to public and private research sponsors, nine institutes supported by Britain's Biotechnology and Biological Sciences Research Council (BBSRC) have formed a consortium known as the Bioscience Network.

The institutes, which include prominent units such as Babraham Institute near Cambridge, the John Innes Centre near Norwich, and the Roslin Institute in Scotland home to the cloned sheep, Dolly - have a joint income of about $£ 150$ million (US $\$ 240$ million) a year, and employ about 2,000 scientists and $400 \mathrm{PhD}$ students.

In a statement issued last week, the institutes say the purpose of the new network is to provide an organization for interacting more effectively with the wide range of sponsors and customers of their research, and to "facilitate interactions between the institutes and other major contributors to the UK science base, such as the research universities".

Many in the institutes feel that the work of governmentfunded laboratories has been unfairly undervalued by government departments in recent years, particularly under the previous

Conservative government, which was keen to find activities considered ripe for 'privatization' through the socalled - and since abandoned - Prior Options exercise.

"The institutes have been through a particularly tough time recently," says Ben Miflin, director of the Institute of Arable Crops Research, and chairman of the new network. Miflin points to the results of a recent survey of citations to work published by institute scientists to rebut claims that institute researchers tend to be less productive than those in universities (see Nature 390, 12; 1997)

"We have been on the defensive for a long time," he says. "This is an opportunity to state our case."

The creation of the network has been welcomed by Sir Alistair Grant, the chairman of the BBSRC, as "an important step in the evolution of the research institutes".

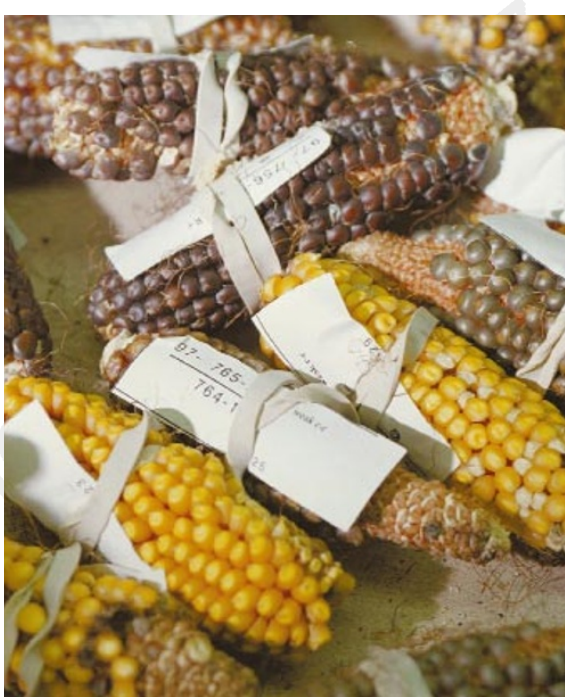

Next in line: samples of mutated corn await genetic analysis at the University of Illinois.

sequencing methods developed by the Human Genome Project, Clutter says, "but we're always in the market for new ideas".

Researchers must submit letters of intent by 2 February and full proposals by 6 April. Grants will go out next September. Clutter says that all of the programme's \$30-\$35 million will be spent in the current year, with future spending contingent on future funds for the programme. A separate announcement will seek proposals for the accelerated sequencing of the Arabidopsis genome, on which the NSF will spend the rest of the $\$ 40$ million.

Peter Raven, director of the Missouri Botanical Garden in St Louis and a powerful advocate of the programme, supports the NSF's plan to fund competing teams taking distinct approaches to the study of many different plant genomes, rather than contracting people to follow an agreed masterplan.

The genomes of corn, rice, wheat and other grasses are "strikingly similar", he says, and the investigation of each will benefit the understanding of the others.

Raven is confident that the NSF can handle the sudden infusion of money into this field. "It is a huge ramp-up," he admits. "But research on plants is heavily underfunded."

NSF officials believe they have convinced the growers of corn and other commodities who sought the initiative that basic research can help to realize their objective of resilient, higher-yield crop varieties. The growers, says Clutter, "didn't really have any idea that fundamental science questions were important to them - but they now understand that".

But the growers are watching, as well as 
learning. Kellye Eversole, a Washington lobbyist for the Corn Growers' Association, says that this year's budget language deliberately gave the NSF plenty of flexibility. "No-one wanted to be real prescriptive," she says. "But if it doesn't go in the right direction, we'll be more prescriptive next year."

Eversole is perplexed by complaints from scientists that Congress imposed the initiative on the NSF. "The scientific community seems to be okay with the president setting priorities, but not with the Congress setting priorities", she says.

These complaints will come more to the fore next year, however, if the NSF's budget comes under pressure and Congress tries to protect the plant genome programme. This year, Bond was able to add the $\$ 40$ million on top of the increased funding requested by the NSF for its normal research grants.

Officials will not say what is in next year's budget, which President Bill Clinton will unveil in February. But early indications are that he may propose no increase at all in the NSF research budget, leaving programmes

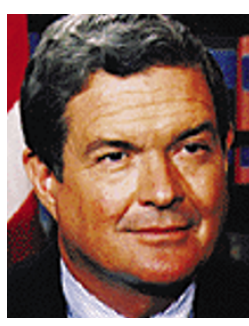

Bond: pulled off bid for extra $\$ 40$ million. to scramble for funds.

Some scientists also worry that Congress will drop the programme if it does not bear early fruit. "The commitment is only for one year," says Andrew Paterson, a plant geneticist at the Texas A\&M University. "That is scary, because it is difficult to quickly make the kind of highvisibility findings which the Congress will recognize as a basis for giving us more support." Senate staff say this concern is misplaced, and that Bond is with the project for the long haul.

"We're talking about a major effort," says Clutter. "What the NSF is doing is jumpstarting something that will set the stage for agriculture of the 21st century. But it isn't something that NSF will be doing for ever."

Other agencies, particularly the US Department of Agriculture, are expected to be involved in the initiative. A multi-agency task force, chaired by Ron Phillips, USDA's chief scientist, is completing a report on what their effort will look like.

The Senate has proposed an immediate injection of an extra $\$ 780$ million over five years into five important areas of agricultural research, of which plant genetics is one. This effort ran into trouble when the House of Representatives went into recess last month without passing a companion bill.

But there is a good chance that USDA funds will be made available for plant genome work. That would mollify those at the land grant colleges who do most USDA research and worry that they will be overlooked by the NSF.

ColinMacilwain

\section{Greenwich observatory's fate hangs in the balance}

[LONDON] The fate of the Royal Greenwich Observatory in Cambridge will be decided tomorrow (12 December) when Britain's main astronomy research funding agency decides whether to throw the centre a lifeline or to carry out its original plan to close its research activities.

The Particle Physics and Astronomy Research Council (PPARC) announced in July, after an intense debate, that it had decided to close the Cambridge site and merge some of its activities with those of the Royal Observatory in Edinburgh to create an Astronomy Technology Centre (see Nature $\mathbf{3 8 8}, 105 ;$ 1997). The $\mathfrak{£} 4$ million (US\$7.2 million) annual savings will be used to support Britain's university astronomy sector.

But the decision to close the Cambridge centre after the merger has been fiercely opposed by the observatory's management, which has put together its own proposal to convert it into a private company. The managers believe they can use the observatory's world-famous name to sell its expertise in telescope design and instrumentation.

Under a business plan presented to PPARC, the observatory would remain in Cambridge, to which it moved less than ten years ago from its previous site at Herstmonceux Castle in Sussex, where it had been located since moving from its original site in London. Initially, half of its contract work would come from PPARC. The rest would be divided between different UK and, eventually, foreign government agencies.

Neil Parker, the observatory's assistant director, says the management is confident its plan makes financial sense, and will enable the observatory to continue as a research organization. But at the beginning of this week it remained clear that the decision will not be an easy one for PPARC.

When they meet tomorrow, members of PPARC's council will examine reports from separate committees that have examined the observatory management's proposals in detail. A committee of senior astronomers has reported on the proposed research plans. And the business plan has been reviewed by an internal audit committee, as well as by the accountancy company Touche Deloitte.

PPARC will not comment on the reports' conclusions. But the reports - and tomorrow's discussion - are almost certainly expected to address three important concerns. One is the question of start-up capital for the new company. The observatory is believed to have asked PPARC to provide $\mathfrak{E} 1$ million to help pay salaries while order books remain thin. There is likely to be considerable debate as to whether the research

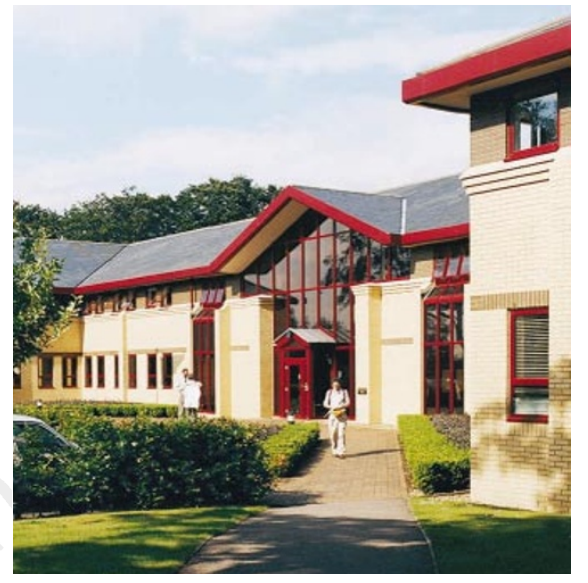

Fighting for life: observatory officials want to keep the Cambridge centre (above) open.

council can afford such a contribution.

The other concerns relate to the implications for PPARC, and for any contracts it funds, if the company proves unable to sustain itself, and to the implications for the University of Cambridge. The observatory's accommodation is owned by the research council on land leased by the university.

The university likes to maintain a distinction between academic facilities, based within the university, and private enterprise, based in the university's science park. It has not yet indicated whether it will allow a private observatory to continue operating from the university's 'academic' sector. In a recent statement, the vice-chancellor, Alec Broers, said the university was in no position to offer financial assistance to the observatory.

Relations between the university's Institute of Astronomy and the observatory have never been close - something Parker says the new company will try to remedy.

If PPARC were to refuse the observatory management's plans, it might revert to the 'fall-back position' of returning the observatory's name to its original home in Greenwich, now part of the National Maritime Museum (see Nature 388, 705; 1997).

The museum's officials are known to be keen on this idea. They want to set up a centre for the public understanding of science. They believe that bringing the name back to Greenwich would boost public interest, particularly in the run up to the millennium.

But, as far as the observatory's managers are concerned, that is the least attractive option. They emphasize that the observatory is at the forefront of research in telescope instrumentation and design, and are tired of the constant references to its past. "The Royal Greenwich Observatory is not a museum," says Parker.

EhsanMasood 